\title{
Mapping the Marriage: Thomas Geminus's \\ "Britanniae Insulae Nova Descriptio" and "Nova Descriptio Hispaniae" (1555)
}

\author{
ALEXANDER SAMSON \\ University College London
}

La représentation du mariage et de la co-monarchie de Philippe et Marie exprimée dans deux cartes géographiques de l'emigréflamant Thomas Geminus, produites en 1555, soutient les aspirations des Habsbourgs dans ce nouveau royaume, dans le but calculéd'attirer le mécénat d'un monarque qui avait un intérêt bien connu pour la cartographie. Malgré le fait que sa carrière, ses relations et ses associés suggèrent qu'il était un protestant engagé, plusieurs raisons l'ont probablement conduit à entreprendre ce projet, une de ces raisons étant au premier chef son statut d'étranger. Ses deux cartes géographiques démontrent que ses convictions religieuses n'ont pas exclu d'emblée sa participation et sa collaboration avec le gouvernement de Marie. En fait, la présence espagnole en Angleterre s'est avérée un stimulant important des entreprises coloniales anglaises, et plusieurs protestants ont profités des connaissances géographiques insurpassées des Habsbourgs. À travers une meilleure connaissance du contexte de la production des cartes géographiques, de ses emplois et de ses modes d'exposition, il est possible de mieux comprendre comment ces cartes reflètent les contours changeant des relations politiques, économiques et culturelles entre l'Espagne et l'Angleterre, exprimant ainsi les volontés politiques et la tolérance qui ont caractérisé les débuts du règne de Philippe comme roi d'Angleterre.

I $\mathrm{n} 1555$ the publisher and engraver Thomas Geminus celebrated the recent marriage of Philip II and Mary Tudor, and the union of their kingdoms, by dedicating maps of England and Spain (see figures 1 and 2) to the newlywed royal couple. ${ }^{2}$ These beautiful, luxurious objects no doubt played a part in Philip's efforts to present himself as an English king, projecting a Catholic, English patriotism, embodied visually in a re-Catholicized England. The map of the British Isles was the first of its kind to be produced in England and was divided along pre-Reformation lines. Both maps need to be seen and understood in the context of a cartographic patronage in early modern Europe that was often concerned less with geography than with the assertion and concretization of political claims, demonstrated by Philip and the Marian regime's use and promotion of mapping projects to pursue their own agendas. 
The Geminus maps reflected the changing contours of diplomatic, economic, and political exchanges between England and Spain. They were part of the process by which Philip and Mary asserted the political claims of their co-monarchy and visually embodied their political authority over their own and each other's kingdoms. ${ }^{3}$ Such large, multi-sheet, copperplate images - the map of the British Isles on two sheets measured $535 \times 745 \mathrm{~mm}$, exceeded by that of Spain on four sheets at $724 \times 895 \mathrm{~mm}-$ were unknown in England before these examples. They required large, expensive printing presses to produce them and, as a result, they were normally destined for display in royal or noble palaces. Geminus almost certainly enjoyed some form of subsidy, if not direct royal patronage, in the context of their production. 4

The map of the British Isles was a reissue, using the same copper plates, of a map by George Lily_-papal editor or censor of maps, a chaplain of Reginald Pole from around $1532^{5}$, and the son of the Latin grammarian William Lily. He had produced the map in 1546 in Rome using information provided by Scottish Catholics. It enshrined a Catholic vision of pre-Reformation England, by omitting dioceses created since the upheavals of the 1530s. It was associated with the publication of Paolo Giovio's Descriptio Britanniae, Scotiae, Hyberniae, et Orchadum (Venice, 1548), ${ }^{6}$ a text with accounts of a number of key English Catholic martyrs supplied by Lily, including one for his friend Thomas More. Pole, a figurehead of Catholic opposition to the Henrician Reformation which had claimed the lives of his mother and brother, was Papal Legate and Archbishop of Canterbury under Mary. The copperplates that arrived in his train therefore firmly associated Geminus with Mary's regime and directly linked him to her foremost counsellor. Another large-scale copperplate map of London, dated tentatively 1553-59, has also been connected with these same circles of patronage. Probably commissioned by the Hanseatic league as a way either of underlining their gratitude for the recent renewal of their trading privileges or to win further support in their struggle with the emerging Merchant Adventurers, its dedicatee may have been Mary herself, her Lord Privy Seal, William Paget, or even Philip himself. The text praising the city was again taken from Paolo Giovio's Descriptio Britanniae, Scotiae, Hyberniae, et Orchadum and may have been composed by George Lily.7 The Geminus reissue, however, demonstrates the influence of another recently rediscovered map which, despite similarly omitting the bishoprics of Oxford, Peterborough, and Gloucester, has been related to the Duke of Somerset's military campaign against Scotland 1547-49, commemorating the English victory at the battle of Pinkie by adding the place name of the nearest town, Musselburgh. ${ }^{8}$ London, depicted differently on this map, is represented identically to Lily by Geminus. However, Musselburgh has been added by Geminus, which strongly 
suggests that he had seen in the course of his researches this hitherto unrecorded woodcut map of Great Britain. It has been suggested that he might have been responsible for an engraving of the battle itself, which would uphold this explanation for the appearance of Musselburgh on the reissue of Lily's map. ${ }^{9}$

Philip's profound interest in cartography and his patronage of numerous geographical projects - from chorographies to city views - is well-attested. He made use of maps to make sense of, and administer, his global dominions as well as using them decoratively, employing plates from Otelius's Theatrum Orbis Terrarum to adorn the antechamber to his private apartments in the Escorial. ${ }^{10}$ His court artist, Anton van dem Wyngaerder, was asked to prepare a series of views of English royal palaces for him as well as detailed city plans of Flanders in $1559 .{ }^{11}$ Later he produced the famous views of the Hispanic kingdoms' principal cities. ${ }^{12}$ Mary probably commissioned a manuscript atlas from the Portuguese cartographer Diogo Homem as a gift for him in the mid-1550s, perhaps to remind him "of their shared dominions and perhaps also of her."13 Philip's calculated attempt to cultivate an image as "Ingles y no español" ["English and not Spanish"],14 as Peter Barber has suggested, almost certainly had a cartographic element. Philip's English descent from Edward III through John of Gaunt had been made prominent early in the campaign to win acceptance for the Spanish marriage in England, with Stephen Gardiner, Mary's Lord Chancellor, publishing a genealogical device that was repeated in the pageants greeting Philip's entry into London after his wedding. ${ }^{15}$ The Geminus maps were most likely to have been displayed in the Privy Gallery at Whitehall that ran from the king's bedchamber to his study. The reprinting of Lily's map celebrated the regaining of a kingdom for Catholicism - a kingdom of crucial strategic importance to Spain in maintaining the connection between the two halves of Philip's dominions in Spain and the Low Countries.

While of limited practical value as a tool for military planning, the Lily map provided a visual focus and overview of the kingdom, including major cities, ports, castles, and strongholds with distances between them, as well as the addition of coastal cities in the Spanish Netherlands. These features were partially determined by its value as propaganda, demonstrating the spatial link between England and the Spanish Netherlands. The original ideological purposes of the map in promoting the Catholic recovery of England, signalled symbolically by the omission of the dioceses created since the break with Rome, shaded seamlessly into the Habsburgs' triumph. England had been a target of several Habsburg military projects between 1546 and 1553. In 1551, for example, the Imperial ambassador wrote concerning Mary's failure to board the ship sent to spirit her away to the Netherlands by her 
imperial cousins: "the English believed his Imperial Majesty, once he had her in his court, would marry her to the Prince of Spain ... [and] wage war against the English for her"; while the Queen Dowager, Mary of Hungary wrote to the Bishop of Arras on the $5^{\text {th }}$ of October in the same year: "the possession of one port there, if we managed to seize one, would enable us to protect our shipping." ${ }^{16}$ England was central to Habsburg strategic interests. This was the fundamental, underlying rationale for Charles v's preference for Mary over the Portuguese bride to whom Philip has almost been betrothed when the opportunity for the new match arose after Edward's untimely death in the summer of 1553 .

Although Lily's map incorporated some improvements, it was already out of date by the time Geminus reproduced it. ${ }^{17}$ It did not take into account the coastal surveys promoted by Henry viII from 1539-40. For example, Mercator's wall map of Europe of 1554, for example, sponsored by Cardinal Granvelle, surpassed Lily's representation of the south coast and East Anglia. As Lily and Geminus had, Mercator omitted the six new bishoprics created by Henry viII: Oxford, Chester, Gloucester, Bristol, Peterborough, and Westminster. In 1564 he published another map of the British Isles, Angliae, Soctiae \& Hiberniae Nova Descriptio that improved further on his earlier map. Of the 40 copies printed by the Plantin press, half were sold to Paris. The Spanish ambassador to England, Guerau de Spes, purchased one, as did an official of the Jesuit College in Douai, and Luis Manrique de Lara, secretary to the Spanish governor of the Netherlands, the Duke of Alba. ${ }^{18}$ Mercator claimed that an unnamed friend had sent the new map to him. ${ }^{19}$ Ortelius was also reticent about its source when he reprinted the map. Peter Barber has argued convincingly-on the grounds of linguistic mistakes in the place names, the accuracy of its depiction of Scotland, and the dismissal of the Brutus and King Arthur legends - that Mercator's "friend" was the Scotsman John Elder, provider of a map for Henry viII in 1543 and the author of a eulogistic account of Philip and Mary's wedding, Letter sent into Scotland (1555).

Philip may also have been behind the authorization of a major new survey of England by John Elder and John Rudd, who later became master of Christopher Saxton. Elder's Letter was the Scottish priest's initial recommendation to Philip, and it is clear that he wholeheartedly shared the Habsburgs' desire to extirpate the Protestant heresy. In the light of the need for better intelligence concerning Scottish geography, Henry vin had made use of Elder to obtain a map for him in $1543 .{ }^{20}$ The "clerk a reddshank" Elder had proposed that Henry marry Edward to Mary Queen of Scots in order to drive away "the forsaid bussheps, which be the Dewils convocacion ... with beelzebubs flesmongers the abbotes" and offered "this plotte 
of the realme of Scotland, vnto your Excellent Maiestie, wherin your highnes shall perceauve and se not onely the descripcion of all the notable townes, castells and abbeis ... but also ... the dangers lying therby with euery port, ryver, loigh, Creke and haven ther, so truly drawyn."21 The Privy Council granted him a passport in 1556, possibly at Philip's behest, for travel related to his cartographical research. ${ }^{22}$ In 1561 he requested a passport to return to Scotland. Sir Nicholas Throckmorton wrote to Cecil from Paris that:

The bearer, Mr. Elder, wishing to pass into Scotland through England, desired his recommendation to Cecil by letters ... Thinks Cecil might draw some good service forth of him, for the French at his departing have given him occasion to think that they could be content to serve themselves by him in Scotland. He is very skilful in drawing plats for situation of countries and declaration of coasts. ${ }^{23}$

Geminus' reprint of Lily's map perhaps met an immediate demand for a map of Philip's new kingdoms. It seems likely that he was ordered to produce it. The realization that it was already outdated was probably what prompted Philip to order a fresh survey based on the evidence available to him in the Royal Library. ${ }^{24}$ In this sense, the reissue of the Lily map was a stop-gap measure and subordinate to Geminus' attempt to attract Philip's patronage with an improved map of Philip's Iberian kingdoms.

Geminus' Hispaniae was only the third, non-Ptolemaic, modern map of the kingdom(s). It included Spain's North African possessions, as well as other strategic places such as Algiers and the kingdom of Fez. This reflected the predominantly Mediterranean focus of Spain's foreign policy, which if anything looked to the East rather than the North, and the greatest threat to Habsburg hegemony, the Ottoman empire. The first map of Iberia had appeared in Venice in 1551, created by Fra Vicenzo Palatino de Corzula under the title Spagna con le distantie de li loci and dedicated to Francisco de Navarra, bishop of Badajoz. ${ }^{25}$ Hieronymous Cock had copied it in 1553. On the only extant copy of this map the three cartouches remain empty, and above the largest are Charles v's coat of arms, the pillars of Hercules, with his motto "Plus Outlre." ${ }^{26}$ Geminus's map derived directly from the latter and was copied by Ortelius for his famous Theatrum orbis Terrarum (Antwerp, 1570). ${ }^{27}$ Hieronymous Cock had presented Philip with an engraved map and plan of Antwerp in honour of his marriage to Mary. ${ }^{28}$ The Geminus map of the Iberian peninsula was more detailed, ornate, and attentive to political organization than that of the British Isles. The dedicatory panel was situated on this map and not on that of the British Isles. This hinted that, although the maps were dedicated to both Philip and Mary, they were really intended predominantly for Philip, an active patron of cartography. 
While the England map had only the English and Scottish royal arms flanked by Tudor roses, Hispaniae was significantly depicted with Philip's English arms, an escutcheon on which England formed part of his honorific blazon.

A wreath surrounded these arms, bound on each side by a ring of pomegranates with their seeds half-exposed. The pomegranate was the personal symbol of Mary and of her mother Katherine of Aragón, a symbol of the dynastic bond repeated by Philip and Mary's union. The pomegranate represented the kingdom of Granada, but was also a symbol of fertility, the most highly prized quality in a royal wife. It was a tragically ironic personal emblem for both mother and daughter. The image of the conjoined arms of England and Spain on the Geminus map of Hispaniae, nestling beneath a closed imperial crown, aped other visual representations of Philip and Mary's joint monarchy, from their royal entry into London on 18 August 1554: "in the heigth of al [a genealogical tree], wer both their armes joined in one, under one crown emperial," 29 to the coinage: "the prince of spain ... is permittid in our english coins to join our english armes with the armes of spain and his fisnamy [with] the quenes, the crowne of England being made over both ther heds in the midest, and yet upon nether of them both." ${ }^{\circ}$ The double-escutcheon twinned England with the other kingdoms over which Philip enjoyed plenum dominium in 1555, as king in his own right, as opposed to successor of Charles v, i.e. from top left, Castile and León, Aragón and Sicily. This can be compared with a manuscript drawing of his arms from an English charter, dating from after the abdication of his father in 1556, which included in addition the arms of Austria, Navarre, Burgundy, and Flanders (see figure 3)..$^{11}$ The double shield has also mutated into a single escutcheon. In heraldic terms, he could have included Austria on the map of Spain, but the focus was on the lands he ruled over at the time and England was granted a prominent place in that chosen scheme.

The notable inclusion of England's arms with Philip's on the map of Spain was a visual emblem of the new political relationship between the two countries and of England's importance within the multinational Habsburg empire. Although it could be argued that England's independence was symbolized by the fact that the map made no reference to Spain, it seems more plausible to suggest that the visual presence of England on Philip's coat of arms on the map of Hispaniae above the dedication was intended to glorify a Spanish monarchy that now included England. The representation—despite the marriage contract, with its numerous stipulations surrounding the nominal power Philip was supposed to enjoy as Mary's consortimplied that England had become one of Philip's territorial possessions. ${ }^{32}$ If the maps were displayed together, as seems likely, the larger size of the Spanish map 
reinforced a new balance of power. In the Queen Mary Atlas produced by Diogo Homem in 1558-59, where the Iberian Peninsula and British Isles are depicted together, there is a blank space where a coat of arms, presumably Philip's, has been scratched off, to the left of the Tudor armorial device. ${ }^{33}$ This historical vandalism sought to erase all trace of a period when England was drawn into the orbit of the Habsburg empire and threatened with becoming a mere satellite state. It contains a unique depiction of the army of Pizarro, conquistador of the Inca empire, and consistently emphasizes Spain's importance, downplaying Portuguese overseas possessions by situating Spain's coat of arms in the far east near the Spice Islands. France is depicted surmounted by an open, non-imperial crown, dismembered in accordance with the belligerent objectives of the Anglo-Spanish axis that declared war in 1557.34

The dedicatory panel on the map of the Iberian Peninsula began with a declaration of the joint-style of Philip and Mary - the most widely circulated assertion of their co-monarchy, in which at the insistence of the imperial ambassadors and in the face of Privy Council opposition, Philip took precedence. It continued:

$\mathrm{He}$, who is the first to work out things not formerly discovered by others and having toiled away upon them does not begrudge them for public advantage, it is generally agreed, serves the state best and contributes to the advancement of learning for all. The next best undertaking to this end, is that of he who strives to the best of his ability to supplement the industry of others, adding to their discoveries and strictly emending their mistakes. We confess that we are among that number in the edition of this map, in which we were eager to show the truth of those most rich Spanish kingdoms as far as it is possible to do so. After we had brought together with diligent study all the maps we knew of, published before by anybody and with accurate industry surveyed and examined them, we realized that they contained much that was nonsensical in the description of the towns: there had even been some mistakes in their names. We noticed also a not unblameworthy number of omissions of them everywhere. However we did not think we ought to mock their efforts, since we are turning our hands to this task after them, especially when having thought out our decision for the purpose of Cosmography as if for a touchstone, we will have changed not a few towns even and their positions_-desired in other places. I have decided to dedicate this our work to none other than your majesties. So that there you can gaze together (with one eye) at these mighty territories of the very large and noble kingdom to the inheritance of which you Philip have been born, the very mighty king, and you $\mathrm{O}$ most Serene queen, to whose name you have been wed. May the mightiest and great God keep your Majesties safe and happy for a long time. At London, T. Geminus. ${ }^{35}$ 
The dedication began with the customary affirmation of Geminus' humanistic agenda, dissociating private profit from the service of the state and "the advancement of learning for all" in the name of "public advantage," even while he emphasized his own labour, "accurate industry", and "diligent study." The dissociation of intellectual work from material considerations in a dedication whose purpose was to obtain material reward for its author, was a typical rhetorical strategy. Having consulted the maps of Paletino (1551) and Cock (1553), Geminus' team had identified mistakes particularly in the naming and placement of towns. It seems likely they consulted Spaniards in Philip's entourage in order to correct these mistakes. Chorography had begun to flourish in the Hispanic kingdoms in the 1540 s under the auspices of royal patronage with Philip's commissioning of Andrés García de Cespedes' General corografia e historia de España and the publication of works such as Pedro de Medina's Libro de las grandezas o cosas memorables de España (Sevilla, 1548), allegedly a pirated recasting of the first official Habsburg chronicler Florián de Ocampo; and Pedro de Alcocer's Historia o descripción de la ciudad imperial de Toledo (Toledo, 1554). ${ }^{36}$ The fact that corrections had been made to the naming, situation, or omission of towns strongly suggests that chorographers were also employed by Geminus to provide greater information about the inland organization of the territories. Geminus imagined the king and queen gazing with "one eye" over their vast territories. While the Hispanic kingdoms belonged to Philip by inheritance, Mary by contrast was merely wed to them. The following section of this essay attempts to explain why Geminus may have presented the Anglo-Spanish treaty in this way in his search for patronage and protection from Philip, a position according to which Mary's title was conceptualized as merely nominal. While on the other hand Philip's claim in England was given solidity through its visual representation in his armorial iconography. There was no attempt to vindicate her dynastic claim as the daughter of Katherine of Aragón or Philip's cousin.

The engraver and publisher, Geminus, was a successful Flemish immigrant from the town of Lixhe or Lexhe, near Liège, whose real name was Thomas Lambrit, Lamberd, or Lambert. An entry on the Denization Roll for 1 July 1544 referred to a "Thomas Lamberd, born in the dominion of the Emperor. In England 20 years," 37 probably the same person. His first appearance in the historical record dates to 1545 with his publication of a pirated edition dedicated to Henry viII of Andreas Vesalius' De Humani corporis Fabrica Libri Septem and De Humani corporis Fabrica Librorum Epitome (Basle: J. Oporinus, 1543), issued under the title Compendiosa totius Anatomie Delineatio (London: Nicholas Hill, 1545). The plates from this anatomical textbook were subsequently recycled by the printer Jacques Grévin, who probably 
obtained them from Geminus' executors around 1562, appearing in re-editions of the Anatomy in 1564, 1565, and 1569. They were also subsequently copied in Juan de Valverde's Vivae imagines partium corporis humani aereis formis expressae (Antwerp: Plantin, 1566). ${ }^{38}$ The elaborate title page and illustrations to the Compendiosa totius Anatomie Delineatio by Geminus were among the earliest quality copperplate engravings carried out in England. The work was dedicated to Henry under the auspices of patronage by the king's favourite, and Protestant, Sir Anthony Denny:

I had no hesitation in publishing whatever might have value and might as far as possible be helpful, especially since last year your Majesty announced to me through your most Christian and very faithful aide-de-chambre, Sir Anthony Dennie, that these same anatomical figures ought to be published. I received this announcement when your Majesty had set out for France for the siege of Boulogne. ${ }^{39}$

Geminus was rewarded for this service with an annuity of $£ 10$ a year from the Privy Purse. ${ }^{40}$ This payment lapsed in Edward's reign, although he received other payments under Edward for work apparently in a medical capacity: "Quarters wages for Midsomer, anno Regni Regis, Edwardi vj to Thomas Gemynous, Surgeon. 1s."41 Geminus was also a maker of surgical and other astronomical instruments. It has been argued that an engraving of various pieces of apparatus at the end of the 1553 edition of the Anatomy, in an English translation by another committed reformer, Nicholas Udall, advertised goods that Geminus manufactured. Udall, despite his religious convictions, had provided an entertainment early in Mary's reign called Respublica, and had produced a translation of the Paraphrases of Erasmus with Mary in $1548 .{ }^{42}$

This translation was dedicated to Edward vi and apparently endorsed his religious settlement. Geminus addressed the king "as the moste hygh and redoubted Prynce Edwarde the v.i. by the grace of God kynge of Englande, Fraunce, \& Irelande, defendour of the Fayth, \& of the Churche of England \& also of Irelande, in earth the Supreme heade." 43 He went on that it was through Edward, "so godly a soueraigne by whose moste gracious bountie I haue my liuyng and beyng here." 44 His representation of himself in the dedication, at this specific historical juncture, as an humble alien artisan placing his technological expertise at the service of the commonwealth had unavoidable associations with religious protection, something his bequest to the Dutch church twenty years later appears to confirm: ${ }^{45}$

I am not my selfe so perfeict and experte in the Englishe tounge that I dare warraunt or trust myne owne dooynges, [so] I haue used the studious peines of Nicholas Udall and certain other learned men whoes exercise in translacions and pennyng in this tounge hath ben (as I understande) not without some fruite to the commen weale ${ }^{46}$ 
Translation was an important political activity at this time for the fledgling Protestant state, and Geminus was keen to flatter Edward's intellectual interests: "ferther consideringe your Maiesties moste tendre zele and earnes will to haue publyshed abrode all good thynges that maye redounde to the encreace of good knowelage and to the fertheraunce of the liberall disciplines." 47 The translator Udall was also a beneficiary of Edward's patronage, being granted a prebend at Windsor in 1551 from where he penned the preface to Geminus' treatise on 20 July 1552. The edition that appeared in 1559 from Geminus' own press was revised with the help of Richard Eden and dedicated to Elizabeth I, although the title page depicted Mary, who presumably had originally been the intended dedicatee, dying before the printing was complete. ${ }^{48}$ Eden, perhaps one of the "learned men" referred to in the earlier dedication, was a client of Sir William Cecil. His first published translation and the first book in English written exclusively about the New World-Sebastian Munster's A treatyse of the newe India ... (June 1553) — had been dedicated to the Duke of Northumberland. In 1555 Eden's influential Decades of the newe worlde or west India had been published, praising "the heroical factes of the Spaniardes of these days, [that] deserue so greate prayse that thautour of this booke (beinge no Spanyarde) doth woorthely extolle theyr doynge aboue the famous actes of Hercules and Saturnus and such other which for theyr glorious and vertuous enterpryses were accoumpted as goddes amonge men." 49 The Protestant exile John Ponet had seized on the Decades in his polemical exposure of Spanish cruelty and barbarity in the New World:

where at the comming thider of the Spaniardes, ther were accompted to be in that countrey nine hundred thousaunt persones, ther were in short time by this meanes so fewe lefte, as Petre martir (who was one of themprour Charles the fifthes counsail there, and wrote this historie to themperour) saieth, it was a shame for him to name..$^{\circ}$

Ponet then argued that what had happened there would shortly happen in England as well. Although Eden's religious commitments saw him forced to resign an office awarded to him in the treasury as a result of Spanish noble favour, he managed to remain in England during Mary's reign, perhaps in part due to the prologue quoted above.$^{51}$ Like Udall, his faith certainly initially proved no bar to favour under the new regime, and it may have been through Udall that Geminus obtained his initial entrée. Alternatively, the privilege may have come to him through his former patron, Sir Anthony Denny who, although a reformer, was a childhood friend of Lily. ${ }^{52}$

At the time of his publication of the maps Geminus was an established publisher at Blackfriars, an area frequented by foreigners, from where-along with the maps 
and the 1559 re-edition of his Anatomy - he also published two scientific treatises by the Protestant Leonard Digges: the Prognostication of right good effect fructfully augmented, contayning playne, briefe, pleasant, chosen rules, to iudge the wether for euer, by the Sunne, Moone, Sterres, Cometes, Raynbowe, Thunder, Cloudes, with other Extraordinarie tokens, not omitting the Aspectes of Planetes, with a brefe Iudgement for euer, of Plentie, Lacke, Sickenes, Death, Warre \&c. (1555) and Boke named Tectonicon (1556). The Prognostication's tide-tables, sundial, and method for working out the time at night using the moon and two stars represented significant innovations in this period, while the Boke named Tectonicon introduced Continental-surveying techniques for the first time to England.53 Digges had been attainted for his involvement in the Wyatt rebellion, having served as a militiaman. He was pardoned on 1 April 1554 and fined a total of $£ 241$, which he finally discharged in May 1558.54 In the dedication of his Prognostication to Sir Edward Fiennes, he referred openly to his imprisonment following the Wyatt rebellion: "Sithe my late troubles (right honorable, and singular good lord) my dutye hath made me careful to procure, that some frute of my studies, might declare me thankefully mynded, towarde youre lordshippe, emonge, other honorable, to whome I owe my self."55 Fiennes, Lord Clinton and Saye, later became Lord High Admiral of England until his death in 1585 and shared Digges' interest in navigation. The publication by him less than a year after release from prison of a treatise on astrology, astronomy and divination might have made him particularly vulnerable to politically motivated attack. He recognized as much in the Epistle to the Reader, in which he referred to the difficulties he had had finding a publisher for his treatise, "titled Tectonicon, a treasure vnto the Masons, Carpenters, and Landmeaters": 56

As the good wil of Printers not had, hath kept the foresayd from you: so I trust the willing minde and excellencie of Thomas Gemini, shal bring them shortly vnto you. Certes my hope is, while life remaineth, not to be vnfruteful to this commune wealth, with study, and practise. .7

Although of scientific merit, Geminus was clearly taking a risk, given other publishers' wariness of Digges' project. The rhetoric of public utility and service here echoed the sentiments expressed by the printer in his own published output. Geminus was directly associated through his own publications and publishing activities with the humanist circles interested in navigation, cartography, and scientific advancement in England, which had surrounded Edward vi from the early 1550 - - men like Sir John Cheke (kidnapped and brought back from continental exile to recant his Protestantism), Leonard Digges, Richard Eden, and John Dee, a friend and pupil of Frisius and Mercator..$^{8}$ 
Geminus has been linked to Mercator, possibly with the Mortlake astrologer John Dee as an intermediary, by a series of astrological instruments, including an astrolabe of c. 1550, another of 1559, and a quadrant dated 1551, that appear to have been direct copies of instruments made by Mercator. ${ }^{59}$ In addition to the maps, Geminus also manufactured two astrolabes in 1555, complementary to those cosmographical endeavours, one of which was employed in the voyage of exploration to Russia, which led to the enfranchisement of the Muscovy Company. ${ }^{60} \mathrm{He}$ was instrumental, in this sense, in some of England's earliest colonial endeavours. For example, after the successful Russian voyage of 1556 , for which Geminus' astrolabe had been employed, Stephen Borough visited the Casa de Contratación in Seville, the pre-eminent map-making establishment in Europe. There he acquired a copy of Martin Cortés' Arte de navigar. Back in England, Borough persuaded the Muscovy Company to sponsor its translation, and in 1561 Richard Eden's The Arte of Navigation was published: "one of the most decisive books ever printed in the English language. It held the key to the mastery of the sea." ${ }^{11}$ Ironically, Martin Cortés himself had been in England with Philip in 1554, and was referred to in a Castilian account of the wedding: "I believe few nations were missing, because there were Spaniards, English, Germans, Hungarians, Bohemians, Flemings, Italians, Venetians, as far as the Marquis del Valle [Martin Cortés] who served for an Indian." ${ }^{2}$ The Habsburg connection, in spite of confessional differences, proved very useful to the advancement of navigation, cartography, and geography in England in the 1550 os and was a spur to English colonial aspirations-as Fresneda, Philip's confessor, warned him. ${ }^{63}$ What is clear from the sketch of the connections and associates of Geminus during this period is that certainly while Philip was in England, those who shared his intellectual interests in cartography and geography were quickly drawn into his service and mutually beneficial relationships, which extended his influence and patronage among important intellectual figures and extended the possibility to them of benefiting from Spain's pre-eminence in this field.

Geminus' will provides further clues to his religious identity. The executor and main beneficiary, his brother Jaspar Lambrit, received: "the disposition of all my Landes, tennements, hereditaments, and patrimony goods as well lying and being within Leighe nighe unto Marke Wesett within the bishopryke of Leuke in the parties of beyond the Sea, as elsewhere wheresoever." 64 Leighe, Lexhe, or Lixhe was a village two miles west of Wesset (Visé in French) and eight miles north of Leuke (Liège). There was no specific mention of landed interests in England, in spite of the fact Geminus had been denizened and in England for over twenty years. His wealth and success in England were apparent both from his will and from the records of the 
Stationers Company. In the spring of 1556 Geminus was assessed for "A Collection to be gathered of the companye by the commandment of the lorde the Maiour and the Courte of aldermen for the howse of brydewell." He made the joint highest contribution with Richard Richardson of 20 pence, which might suggest he was moneyed, perhaps after being rewarded for his cartographic endeavours, although no record of any payment survives. ${ }^{65}$ The will contained nothing in keeping with a commitment to traditional forms of piety. There was a small bequest to the poor of Blackfriars and another more suggestively "to the poore people resorting to the Dutch church within the Cittie of London ijs, to be distributed to and amongest them by the discretion of my saide executor." ${ }^{6}$ The Dutch church in London was a focal point for religious refugees and radicals under Edward. It could be argued that his conversion might have taken place subsequent to the Elizabethan religious settlement; however, his connections work against this assertion. It seems almost certain that Geminus was a committed Protestant. His landed interests retained for so long in "parts beyond the sea" are surprising, however, if he was a religious refugee, since land was normally confiscated in those cases. His initial reason for moving to England is likely to have been economic if he arrived as early as 1524 .

The dedication of maps to Philip and Mary, sovereigns whose co-monarchy was so closely associated with the return of papal jurisdiction, and his apparent support of Philip's title as King of England, symbolized by the merging of England's royal coat of arms with those of Philip's other kingdoms on the dedicatory cartouche, might seem surprising in light of Geminus' apparent Protestant faith. The maps, and his attempt to secure patronage by appealing to Philip's well-known interest in geography and gain special access to the superior cartographical knowledge of Habsburg Spain, however, do not necessarily suggest a cynical and expedient accommodation to successive religious settlements. Geminus was not alone among Protestant intellectuals who were initially drawn into the ambit of the regime - the evangelical Richard Grafton, for example, publisher of the "Great Bible," was responsible for the pageants which had greeted Philip for his royal entry into the city of London, enthusiastically welcoming him as lord and culminating in images of the alienation of English sovereignty. ${ }^{67}$ It did not imply indifference to religious debate or a broad conscience. One explanation may lie in Geminus's status as an alien, which made him vulnerable in the context of religious backlash. On 17 February 1554 Mary had proclaimed the expulsion of "seditious aliens" in England "fleeing from the obeisance of the princes and rulers under whom they be born (some for heresy, some for murther, treason, robbery, and some for other horrible crimes)." 68 The legislation, which had been canvassed for by the Emperor, was aimed specifically to root out religious radicals 
who had sought refuge in Edward's England. Anyone not denizened since Henry VIII's reign was obliged to leave. If Geminus is to be identified with the 1544 entry in the Denization Roll for a Thomas Lamberd in England since 1524, then he fell outside the scope of the expulsion. However, the evidence for Geminus's reformed religious faith, his connections with Udall, Eden, Digges, Mercator, and Edward VI, alongside the external evidence of his will, make it likely that his situation, despite falling outside the scope of the expulsion, was precarious.

Two events coincided with the publication of the maps. An entry in the annals of the Royal College of Physicians ${ }^{69}$ from 20 May 1555 alludes to "Thomas Geminus, Flander" appearing before their council where he was fined for an unspecified offence. $7^{\circ} \mathrm{He}$ had perhaps overstepped the boundaries of his competency at a time when the Royal College was attempting to force conformity on the medical profession. In lieu of a fine, Geminus printed a letter, which set out the new powers of the College's investigators, extending their jurisdiction beyond London, over the universities..$^{71}$ At almost the same time, Geminus was in trouble with the authorities of the Stationers' Company. According to the Register of the Company of Stationers, a fine of twelve pence was received on the $21^{\text {st }}$ July 1555 from "thomas Gemyne, stranger, for transgressynge the ordinaunces of this howse, callynge a brother of the companye a flasse [false?] knave." 72 His questionable religious credentials and association with the suspect alien community at Blackfriars, many of whom had been expelled shortly before, might well have prompted him to seek royal protection quickly after the establishment of the new regime with Philip and Pole's arrivals in 1554. By placing his scientific expertise at the disposal of the regime, he might have been attempting to secure protection from enemies or rivals in the Stationer's Company. Another obvious reason for him to seek Philip's favour was that he was one of the most active patrons of cartographic projects and a likely source of lucrative employment for someone of Geminus' talents.

The Anglo-Spanish marriage provided opportunities even to committed Protestants like Geminus to profit from the wealth of cartographic knowledge and expertise possessed by the Habsburgs. The dedication affirmed the engraver's loyalty to Philip first and foremost as a Flemish-speaking subject of the Emperor, as well as his tacit support for Habsburg political aspirations in England. Many in England at this time welcomed Philip as a way of righting gender relations thrown off balance by Mary's unprecedented female rule. England's symbolic incorporation alongside Sicily, Brabant, and Flanders reflected perhaps the priorities of a stranger with little stake in promoting xenophobic nationalist sentiment in England. It provided Philip with a visual overview of his achievements up to that point, at whose heart lay Spain. 
It may not be possible to definitively explain why a Protestant like Geminus might have sought to engage with Philip and Mary's regime so ostentatiously-whether it was insecurity in the wake of the Marian religious backlash, an interest in cartography that transcended religious differences, or knowledge that was at once transnational and yet in other ways politically sensitive. Although, there is no record of Geminus being rewarded for his mapping endeavours, the maps provide further evidence of Philip's early advocacy and support for toleration. It was not until the autumn of 1555 that the persecution fanned out from its initial exemplary, high profile victims to the rest of the country. Whatever the religious sensibilities of their engraver, the maps projected a vision of new political realities, symbolizing the complexity of and range of responses to a union that, while Catholic, was also associated with Geminus's religiously mixed native land and held out the possibly that the two might be united under one ruler, the successor that Philip and Mary were to lack.

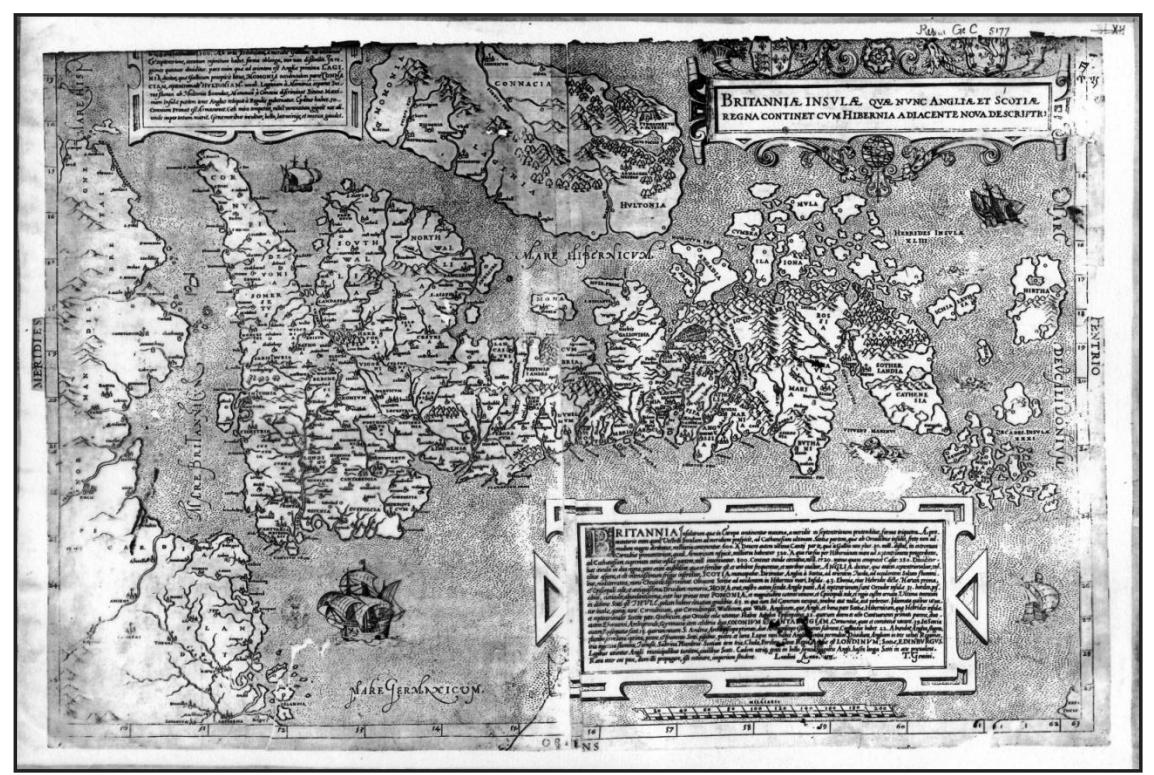

Figure 1 : Britanniae Insulae Nova Descriptio (London: Thomas Geminus, 1555), Bibliothèque nationale de France. 


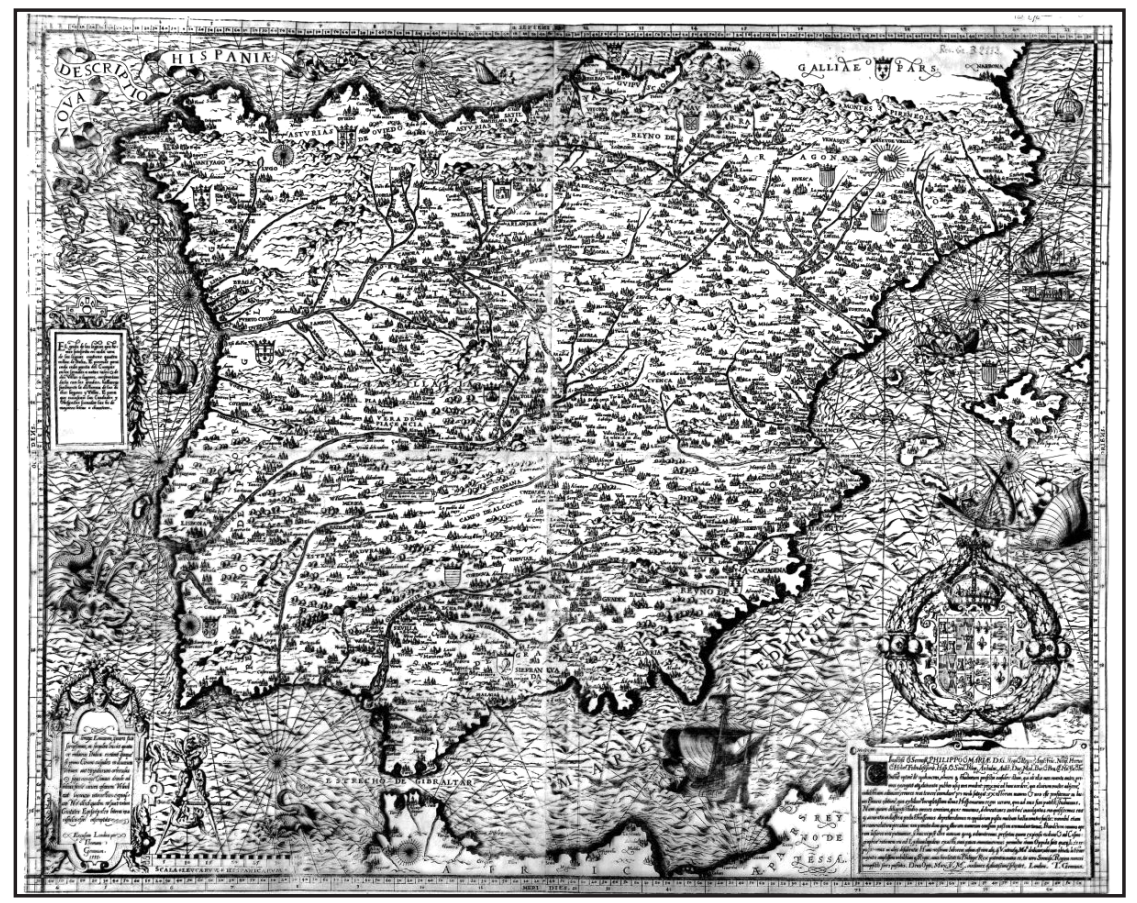

Figure 2: Nova Descriptio Hispaniae (London: Thomas Geminus, 1555), Bibliothèque nationale de France

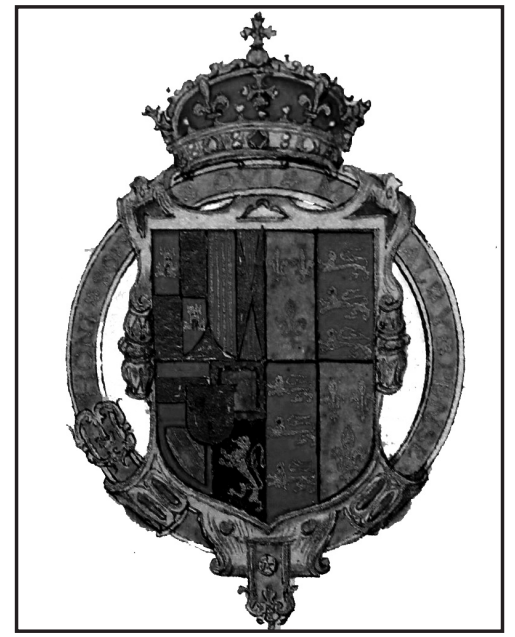

Figure 3: Coat of arms of Philip II of Spain from a book on salt and fishery, Pepys Library, Cambridge. 


\section{Notes}

1. The unique surviving copies of the two maps are at the Bibliothèque Nationale in Paris at Res. Ge. B.2112 and Res. Ge. C.5177. A copy of the map of Spain, held in Wroclaw, Poland, was destroyed during World War II. I would like to express my profound gratitude to Peter Barber for all his help with this article, supplying invaluable information that allowed me to plug the many gaps in my knowledge of the history of cartography. Any errors that remain are my own responsibility.

2. Robert W. Karrow, Mapmakers of the $16^{\text {th }}$ Century and Their Maps (Chicago: Speculum Orbis Press, 1993), p. 252.

3. For a discussion of the social, cultural, and ideological uses of maps, globes, and cartography in the early modern period, see Jerry Brotton, Trading Territories: Mapping the Early Modern World (London: Reaktion Books, 1997), Introduction, pp. 17-46.

4. Peter Barber, “The Copperplate Map in Context," in Tudor London: A Map and a View, ed. Ann Saunders and John Schofield (London: Topographical Society, 2001), pp. 16-32, p. 19, and "Court and country: English cartographic initiatives and their derivatives under Henry VIII and Philip and Mary,” in Actas XIX Congreso Internacional de historia de la cartografía (Madrid: Ministerio de Defensa, 2002), p. 2.

5. J. B. Trapp and Hubertus Schulte Herbrüggen, "The King's Good Servant": Sir Thomas More 1477/8-1535 (London: National Portrait Gallery exhibition catalogue, 1977), p. 135 .

6. Peter Barber, "England II: Monarchs, Ministers, and Maps, 1550-1625," in Monarchs, Ministers and Maps: The Emergence of Cartography as a Tool of Government in Early Modern Europe, ed. David Buisseret (Chicago and London: University of Chicago Press, 1992), p. 62

7. See Barber, “The Copperplate Map in Context," esp. pp. 23-5.

8. Peter Barber, "Putting Musselburgh on the map: two recently-discovered cartographic documents from the 'Rough Wooing'," in Mappae Antiquae Liber Amicorum Günter Schilder, ed. Paula van Gest-van het Schip and Peter van der Krogt (Amsterdam: Hes \& De Graaf, 2007), pp. 327-38, esp.pp. 334-35.

9. Barber, "Putting Musselburgh on the map," p. 334.

10. Peter Barber, The Queen Mary Atlas: Commentary (London: Folio Society, 2005), pp. $41-42$.

11. Barber, “The Copperplate Map in Context," p. 31, note 86.

12. See Spanish Cities of the Golden Age: The Views of Anton van den Wyngaerder, ed. Richard L. Kagan (London: University of California Press, 1989).

13. Diogo Homem, The Queen Mary Atlas (London: Folio Society, 2005), a facsimile edition of British Library, Additional Ms 5415A, p. 45.

14. Biblioteca Nacional Madrid, Ms 9937: Florian de Ocampo, Sucesos Acaecidos, 15501558 and $1521-1549$, fol. $126 \mathrm{v}$.

15. For the device see British Library Royal Manuscript $12 \mathrm{~A}$ xx. 
16. Calendar of Letters and Despatches Relating to the Negotiations between England and Spain, vol. X, pp. 145 and $378-79$.

17. I rely heavily in this section on Peter Barber's "The British Isles" in The Mercator Atlas of Europe: Facsimile of the maps by Gerardus Mercator contained in the Atlas of Europe, circa 1570-1572, ed. Marcel Watelet (Pleasant Hill, or, USA: Walking Tree Press, 1998), pp. 43-77, esp. p. 49.

18. Geoffrey Parker, "Maps and Ministers: The Spanish Habsburgs," in Monarchs, Ministers and Maps: The Emergence of Cartography as a Tool of Government in Early Modern Europe, p. 79

19. The cartouche reads: "Obtulit mihi ... amicus quidam singularis hanc Britannicarum insularum descriptionem, multa sane diligentia et summa fide congestam, rongans ut pro nostro modulo concinnatam in multa exemplaria diffunderem, quod cum amico denegare nollem \& a tam absoluto \& doctorum hominum conspectu digno opere manum subducere iniquum iudicarem, eam tibi qualem accepti exhibeo," reproduced in Barber's “The British Isles," p. 55.

20. On the patronage context of the Geminus maps see Peter Barber, "Court and country: English cartographic initiatives and their derivatives under Henry viII and Philip and Mary," Actas. XIX Congreso Internacional de Historia de la Cartografía (Madrid: Ministerio de Defensa, 2002), pp. 1-12, 8-11, and Barber, “The British Isles,” pp. $46-$ 50.

21. British Library, Royal MS $18 \mathrm{~A}$ xxxVIII, fo. $1 \mathrm{v}$ and $3 \mathrm{v}-4 \mathrm{r}$. His principal target was the Catholic Cardinal David Beaton, who championed the Franco-Scottish alliance against Anglophiles associated with calls for Protestant reform.

22. Acts of the Privy Council, v, p. 266. $3^{\text {rd }}$ May 1556.

23. Calendar of State Papers Foreign, (1561-62) ed. Joseph Stevenson (London: HMso, 1866), p. 455 , no. $743.24^{\text {th }}$ December 1561.

24. Barber's “The British Isles,” p. 69.

25. Geoffrey Parker, "Maps and Ministers."

26. See Günter Schilder, Monumenta Cartographica Neerlandica, 5 vols. (Uitgeverij 'Canaletto', Alphen aan den Rijn, 1987), vol. II, pp. 91-97.

27. Robert W. Karrow, Mapmakers of the $16^{\text {th }}$ Century and Their Maps (Chicago: Speculum Orbis Press, 1993), p. 252.

28. Richard Kagan, "Philip II and the Geographers," in Spanish Cities of the Golden Age: The Views of Anton van den Wyngaerder, ed. Richard L. Kagan (London: University of California Press, 1989), pp. 40-53, 43.

29. John Elder, "John Elder's Letter," in The chronicle of Queen Jane and of two years of Queen Mary and especially of the rebellion of Sir Thomas Wyatt, ed. John Gough Nichols, Camden Society XLVIII (London: Camden Society, 1850), p. 150.

30. The lamentacion of England (n. p., 1557), p. 10.

31. Cambridge University MS Pepys Library 1663: Nova Anglorum per mare Cronium ad Moscovitas Navigatio, authore Clemente Adam, Regiorum puerorum institutore, 1554, p. 1 
32. The marriage contract was hedged around with limitations on Philip's authority as king of England, preventing him from disposing of a personal patrimony in England, forcing an English household on him, and prohibiting him from removing Mary or their heirs from the country.

33. See British Library Additional Manuscript 5415 A.

34. See Barber, The Queen Mary Atlas: Commentary, pp. 45 and 63-64. Homem had fled to England in 1544 and appears to have remained until 1559 when the atlas was probably completed.

35. The Latin reads: ' Inuictiss \& Sereniss PHILLIPPO \& MARIAE D. G. Regi \& Regina Angl: Frác. Neap. Hierus \& | Hiber. Fidei defésorib. Hisp \& Sicil. Prícip. Archiduc. Aust. Duc. Med. Bur. \& Bra. Com. Ha. Fla \& Tir. | [Decorative capital] Constat optime de repub. Mereri, communi q; studiorum profectui consulere illum, qui ab aliis non inuenta antea, $\mathrm{pri}=\mid$ mus excogitet atq: elaborata publico usuj non inuideat: proxime ad hunc accedere, qui aliorum inuestis adijcere, | industriam adiuuare, errores non tenere emendare pro uirili satagat: ex istorum numero \& nos esse profitemur in hu= | iuis Pinacis editione, qua exhibere locupletissimi illius Hispaniarum regni ueram, quo ad eius fieri potest, studuimus. | Nam quum diligenti studio omnes omnium, quas nouimus, delineationes antehac inuuglatas conquisissemus eas $\mid \mathrm{q}$; accurata industria perlustrassemus deprehendimus in oppidorum profitu multum hallucinatos fuisse: nonnihil etiam | in nomenclatura peccatum: non poenitendum quoq; illorum numerum omissum passim animaduertimus. Proinde non omnino ope $=\mid$ ram lusuros nos putauimus, si huic rei post illos manum quoq; admoueremus, presertim quam expenso iudicio \& ad Cosmo $=\mid$ graphia rationem ceu ad Lydium lapidem exacto, non pauca immutuerimus permulta etiam Oppida suis quaeq; locis $\mathrm{re}=\mid$ profuerimus in alijs desiderata Hunc nostrum laborem uisum est non alii q; v.utriusq; Mati. Dedicare, ubi uno obtutu lustrare | ingentes amplissimi nobilissimi q; Regni, cuius hereditati tu Philippe Rex potentiss natus es, tu uero Sereniss. Regina nomini | innupsisti fines possitis. Deus Opti. Max v. M. incolumes q; diutissime felicitet. Londini. T. Geminus. |' (my translation).

36. See Richard Kagan, "Clio and the crown: writing history in Habsburg Spain," in Spain, Europe and the Atlantic World: Essays in Honour of John H. Elliot, ed. Richard Kagan and Geoffrey Parker (Cambridge: Cambridge University Press, 1995), pp. 7399; and my article "Florián de Ocampo, Imperial Chronicler, Habsburg Propagandist and Historical Commentator: The Uses of History in Early Modern Spain," Forum for Modern Language Studies 42 (2006), pp. 339-54.

37. See William Page (ed.), Letters of Denization and Acts of Naturalization for Aliens in England 1509-1603 (Lymington: Huguenot Society, 1893).

38. On these bibliographical details, see ibid, pp. $42 \mathrm{ff}$.

39. Thomas Geminus, Compendiosa totius anatomie delineatio (London: fac. ed. of the first English edition of 1553 by Nicholas Udall, Dawson's of Pall Mall, 1959), intro. by C. D. O’Malley, p. 12. 
40. Letters and Papers Foreign and Domestic, Henry viII, Vol. XXI: 1546, Part I, no. 963: '94. Thomas Geminus, “ingraver” Annuity of 10 l. during pleasure. Preferred by Mr. Dennye'.

41. Thomas Vicary, The anatomie of the bodie of man (1548 ed. reissued by Surgeon of St Bartholomew's 1577), ed. F. J. and Percy Furnivall, Early English Text Society Extra Series, No. LIII (London: Oxford University Press, 2nd ed. 1930), pp. 117-18.

42. Douglas Rutledge, "Respublica: Rituals of Status Elevation and The Political Mythology of Mary Tudor," Medieval and Renaissance Drama in England 5 (1991), pp. 55-68; and Greg Walker, The Politics of Performance in Early Renaissance Drama, (Cambridge: Cambridge University Press, 1998), Chapter 5 ("Dramatic justice at the Marian Court: Nicholas Udall's Respublica”), pp. 163-95.

43. Geminus, verso of dedication.

44. Geminus, verso of dedication.

45. Geminus, verso of dedication.

46. Geminus, verso of dedication.

47. Geminus, verso of dedication.

48. Arthur M. Hind, Engraving in England in the $16^{\text {th }}$ and $17^{\text {th }}$ Centuries: A Descriptive Catalogue with Introductions, 3 vols. (Cambridge: Cambridge University Press, 1952), Part 1: The Tudor Period, pp. 39-58.

49. Richard Eden, The Decades of the newe worlde or West India (London: William Powell, 1555), sig. a ii r. See also David Waters, The Art of Navigation in English in Elizabethan and Early Stuart Times (London: Hollis and Carter, 1958), pp. 86-87.

50. John Ponet, A Treatise of Politike Power (1556), sig. Fvii $\mathrm{r}-\mathrm{v}$.

51. See Christina Garrett, The Marian Exiles 1553-1559: A Study in the Origins of Elizabethan Puritanism (Cambridge: Cambridge University Press, 1938).

52. See David Starkey, The Reign of Henry virI: Personalities and Politics (London: Collins \& Brown, 1991), pp. 132-36 and Trapp and Herbrüggen, "The King's Good Servant," p. 135 .

53. See Waters, pp. 96-97.

54. David Loades, Two Tudor Conspiracies (Cambridge: Cambridge University Press, 1965), pp. 50, 81, 112, 116-21, 254.

55. Leonard Digges, A Prognostication of Right Good Effect, fructfully augmented etc. (London: Thomas Geminus, 1555), sig. *iii r. [sTC 6860].

56. Digges, sig. *iii v.

57. Digges, sig. *iii v.

58. The Mercator Atlas of Europe: Facsimile of the maps by Gerardus Mercator contained in the Atlas of Europe, circa 1570-1572, ed. Marcel Watelet (Pleasant Hill, oR, USA: Walking Tree Press, 1998), p. 45.

59. On this see Gerard L'E. Turner, Renaissance Astrolabes and Their Makers (Basingstoke: Ashgate Variorum, 2003), ch. 9 ("A Tudor Astrolabe by Thomas Gemini and its Relationship to an Astrological Disc by Gerard Mercator”), pp. 400-409. On Geminus as an instrument maker see the same author's Elizabethan Instrument Mak- 
ers: The Origins of the London Trade in Precision Instrument Making (Oxford: Oxford University Press, 2000).

6o. Waters, pp. 103-104.

61. Waters, pp. 103-104.

62. Biblioteca Nacional Madrid, Manuscript 9937: Florian de Ocampo, Sucesos Acaecidos, 1550-1558 and 1521-1549, fol. 133v: 'Creo que faltavan pocas naciones, porque avia espanoles, Ingleses, Alemanes, Ungaros, Bohemios, Flamencos, Italianos, Verinos[?], hasta el Marques del Valle, que servia por indio'. My translation.

63. H. F. M. Prescott, Mary Tudor: The Spanish Tudor (London: Phoenix, 1952 repr. 2003), p. 478.

64. The will is reproduced by O'Malley in Thomas Geminus, Compendiosa totius anatomie delineatio, p. 32 . It is dated $27^{\text {th }}$ May 1562 Prerogative Court of Canterbury (14 Streat).

65. See note 32 .

66. Geminus, p. 32 .

67. See my article "Changing Places: The Marriage and Royal Entry of Philip, Prince of Austria, and Mary Tudor, July-August 1554," Sixteenth Century Journal 36 (2005), pp. 766-67.

68. Tudor Royal Proclamations: Vol. 2 The Later Tudors (1553-1587), ed. P. Hughes and J. Larkin, (London: Yale University Press, 1969), p. 31.

69. The Company of Barbers and Fraternity of Surgeons had been united by act of Parliament on 25 th July 1540 to form the Royal College of Physicians (an event commemorated in a painting attributed to Holbein).

70. 'Examinati \& castigati sunt ... Thomas Geminus flander', see John Venn, The Works of John Caius, M. D. Second Founder of Gonville and Caius College and Master of the College 1559-1573, ed. E. S. Roberts (Cambridge: Cambridge University Press, 1912), 'Annalium Collegii medicorum Londini Libe, Anno 1555 institutus, Johanne Caïo preasidente \& autore', p. 22.

71. Venn, pp. 36-37: 'vltimo per Reverendissimum Edmundum Bonnar episcopum Londinensem, sine cuius auctoritate nemini liceat quicquam imprimere, curauimus eas imprimendas per Thomam Geminum, mulctae nominae, quam alioqui impendisset numerata pecunia, impressae autem sunt Anglice 200 in haec verba'. The letters were dated $20^{\text {th }}$ September 1556 .

72. Edward Arber, ed., A Transcript of the Company of Stationers of London, 1554-1640, 5 vols. (London: Privately printed, 1875), vol. 1, p. 44. See also E. Gordon Duff, A Century of the English Book Trade (London: Bibliographical Society, 1905), p. 54. 